\title{
地震探査により推定された福井地震断層と その地震学的考察
}

\begin{tabular}{|c|c|c|c|}
\hline 京都大学理学部地球物理学教室 & 天 & 池 & 文 \\
\hline 京都大学防災研究所附属北陸微小地震観測所 & 竹 & 内 & 文 \\
\hline 京都大学防災研究所 & 春日 & 茂 & - 古川 \\
\hline 京都大学防災研究所附属北陸微小地震観測所 & 平 & 野 & 憲 \\
\hline
\end{tabular}

\section{Seismic Exploration of the Buried Fault Associated with the Fukui Earthquake, 1948 and its Tectonic Implications}

\author{
Fumio AmaIke \\ Department of Geophysics, Faculty of Science, Kyoto University \\ Fumiaki TAKEUCHI \\ Hokuriku Microearthquake Observatory, Disaster Prevention \\ Research Institute, Kyoto University \\ Shigeru KASUGA ${ }^{1)}$ and Nobuo HURUKAwA ${ }^{2)}$ \\ Disaster Prevention Research Institute, Kyoto University \\ Norio Hirano \\ Hokuriku Microearthquake Observatory, Disaster Prevention \\ Research Institute, Kyoto University
}

(Received May 7, 1984)

The past activity of the Fukui Earthquake fault prior to the 1948 event is unknown because the fault is covered by a thick deposit. We estimated the depth of the basement for a profile across the fault by means of seismic exploration using an air-gun as source apparatus as well as by the delay times determined by two natural earthquakes. The basement in the western side was obtained to be deeper by $50 \sim 200 \mathrm{~m}$ than that in the eastern side. The basement estimated in this work, the results of leveling survey before and after the earthquake, the present topography, and the boundary shape between the alluvium and the diluvium across the fault suggest the recurrence of earthquakes associated with this fault. The mean rate of displacement is estimated to be $0.1 \sim 1.0 \mathrm{~m} / 1,000$ years.

\section{§1.はじめに}

福井地震（1948 年 6 月 28 日）は，M7.3 といら規模のわりには多くの被害をもたらした

昭和 58 年 4 月 26 日発表

1) 現所属: 海上保安庁水路部

2) 現所属: 建設省建築研究所 


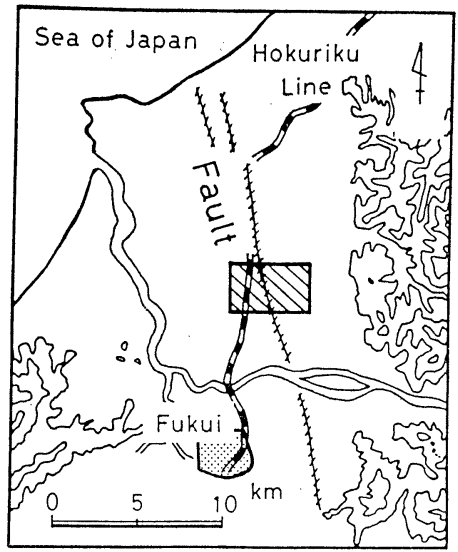

Fig. 1. Location of a buried fault in the Fukui plain associated with the Fukui Earthquake [TSUYA (1950)]: A number of fissures and cracks appeared along the barbed lines. Our observations were carried out in the hatched square in the figure.
地震として知られている[宇佐美 (1975) ].この地震に伴ない福井平野 には無数の地割れが生じたものの, 地 表に明瞭な断層地形は現われなかつた。 ところが地震後, 水準測量や三角測量 の改測が行なわれた結果, 福井平野の 地下に断層運動が起きていたことが見 出された。 また地表の地割れを結んで 得られる NNW-SSE 方向の長さ約 $25 \mathrm{~km}$ に及ぶ帯状域は, 測量結果の隆 起・沈降の境界とも一致し, これが地 震断層の走向であると推定されている [TSUYA (1950)].これを Fig. 1 に 示す. 図中, 断層沿いのハッチ部分は 多くの地割れが生じたことを示してい る.この断層は主要には水平変位約 $2 \mathrm{~m}$ の左横ずれ断層であるが, 断層の

東側が西側に比べ最大約 $70 \mathrm{~cm}$ 隆起した垂直変位も伴なつていた [TSUYA (1950)].

この上下変位量は, 種々の物理探査で検出するには不十分な大きさであるが，もし断層の同 一場所で相当回数の地震がくり返し発生し変位が累積しているならば, これを検出できる可能 性がある.ただ,この地域では 1948 年の地震に匹敵する地震は歴史上知られておらず [TSUYA (1950) ] , 「日本の活断層」 [活断層研究会 (1980)] にも福井地震断層の確実度・活動度・平均 変位速度は記入されていない。

一つの断層がくり返し動くかどらか, また動くとすればどの程度の周期で過去に何回動いた かといらことは重要な問題であり, 従来主として地質学的・地形学的手法を用いて調べられて きた. しかしながら, 福井地震断層は平野部の厚い堆積層に覆われており, しかも地表に過去 の地震の明瞭な痕跡を残していないため，その履歴はほとんどわかつていない。これを明らか にするためにも，物理探査の手法を用いて地下構造を調べる意義は大きい.

既にこの地域では地下構造を探るためにいくつかの探査が行なわれている. 福井地震直後, 吉川 (1949) は福井平野の 13 か所で屈折法による地震探査を行なつた。 それによると，丸岡 の東側で地下構造の急変が存在する他は, Fig. 1 に示された断層沿いに断層構造は報告されて いない。ただしこのときは観測を行なつたほとんどの場所で基盤までの深度を求めるに至つて いない。河野・他 (1981), TAKEUCHI et al. (1983) による重力異常の研究は, 断層沿いに 100 〜数 $100 \mathrm{~m}$ の基盤のくい違いが存在する可能性を示している.

以上の背景のもとに, 我々は地震探查の手法を用いて福井地震断層の探査を行なつた．以下 にその結果を述べる.なお本研究と前後して重力 [TAKEUCHI et al. (1983)], 全磁力 [竹内・ 他 (1983a) ] , $\gamma$ 線 [貞広 - 見野 (1983) ], やや長周期微動 [古川 - 他 (1983，1984); 春日 (1983) ] の研究も行なわれている. これらの探査の概要は竹内・他 (1983b) に紹介されてい る. 


\section{§2.エアガン震源を用いた観測と記録の走時}

\section{1 エアガン震源を用いた観測}

エアガン震源は威力は大きくないが，記録の再現性が良いためスタッキングを行ない， $/ \mathrm{N}$ 比を向上させれば，比較的遠方まで良質の記録を得ることができるという長所を持つている. AMAIKE et al. (1982), 天池・他（1984）は京都盆地東南部において震源にエアガンを採用し， 数百 $\mathrm{m}$ の深さにある基盤からの明膫な反射波を観測した。 今回の観測でも, 事前に基盤の深 さが京都盆地と同程度と考えられたため，震源には扱い易い大きさのエアガン (BOLT 5500 DHS, 5 inch $^{3}$ )を採用した [天池・他 (1984) 参照]. 圧力源には窒素ガスを用い，圧力はほぼ 80 気圧で使用した。窒素は初期圧力 150 気圧, 容積 $47 l$ の市販品（ボンベ入り）を利用し た。

観測計器としては速度型換振器（上下動，固有周波数 $8 \mathrm{~Hz}, 16$ 個), 直流増幅器 (手製, 倍率 $20 \sim 10,000$ 倍), ディジタルレコーダ (TEAC DR1000, 12 ビット, 16 チャンネル) を用い，記録は 2 ミリ秒毎にサンプリングしディジタルデータとして磁気テープに採録した。

観測場所は福井平野の北東部, 福井県坂井郡坂井町にあり (Fig. 1), 福井地震断層を横断す ると思われる場所に長さ約 $1.8 \mathrm{~km}$ の測線をほぼ東西方向に設けた (Fig. 2). Fig. 2 で LL'が測線を示し, 観測点はほぼ 25 30 m おきに 60 点（15 成分ずつ 4 回に分けて観測）設 けた。

震源 $(\times)$ はS $1 \sim 4$ の 4 点設け, エアガンを順次移動させてショットを行なつた. エアガ ンは水中で使用するため, どの震源も用水路（田島川, 兵庫川）を利用した. SP1・SP3・SP4 では既設の橋の上から，SP2 では川幅約 $6 \mathrm{~m}$ の田島川に梯子をかけてその上から，エアガン を水中に下ろした，震源の深さはいずれも水面下 $1.0 \sim 1.5 \mathrm{~m}$ である.

観測には 1982 年 8 月 5 日から 12 日までの 8 日間を要し，その間人員 7 名が車 4 台を使用 した.

\section{2 エアガン震源による記録と走時}

エアガン震源の記録は $\mathrm{S} / \mathrm{N}$ 比を改 善するために $30 \sim 180$ 回のスタッキン グを行なつた。 その際, あらかじめ良 好な記録のみを選び出すといら作業を 行なつている [天池・他 (1984) 参照]. さらに記録には $15 \sim 50 \mathrm{~Hz}$ のディジ タル・バンドパスフィルタ[斉藤 (1978)]をかけている.以上のような 処理を行なつて得られた記録が Fig. 3 に示されている. $\Delta$ は震源からの水平 距離であるが，正符号は震源から東方 向，負符号は西方向であることを示し ている.な拈記録とも振幅の大きな 表面波部分はカットされている.

当初, 主として基盤からの反射波を

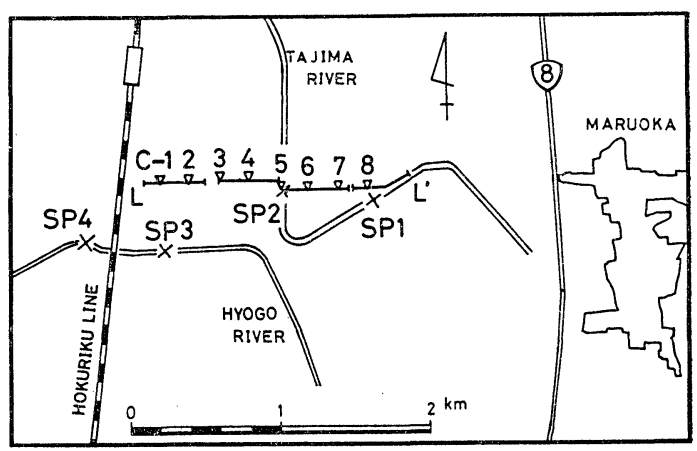

Fig. 2. Enlarged view of the investigated area with four shot points $(x)$, SP1 to SP4, and observation line $\left(\mathrm{L}-\mathrm{L}^{\prime}\right)$ including 60 measuring points. We observed by chance also an earthquake $\mathrm{E} 1$ on a part of the observation line (C-5 C-7) and another earthquake E2 at C-1 through C-8. 
とらえるべく実施された観測であつたが，反射波は他の波群との分離が悪い，あるいは振幅が 十分でない等の理由で解析には不十分な記録であつた。そこで, ここでは特に $\mathrm{P}$ 波初動部に注 目して屈折波探査としての解析を試みた。

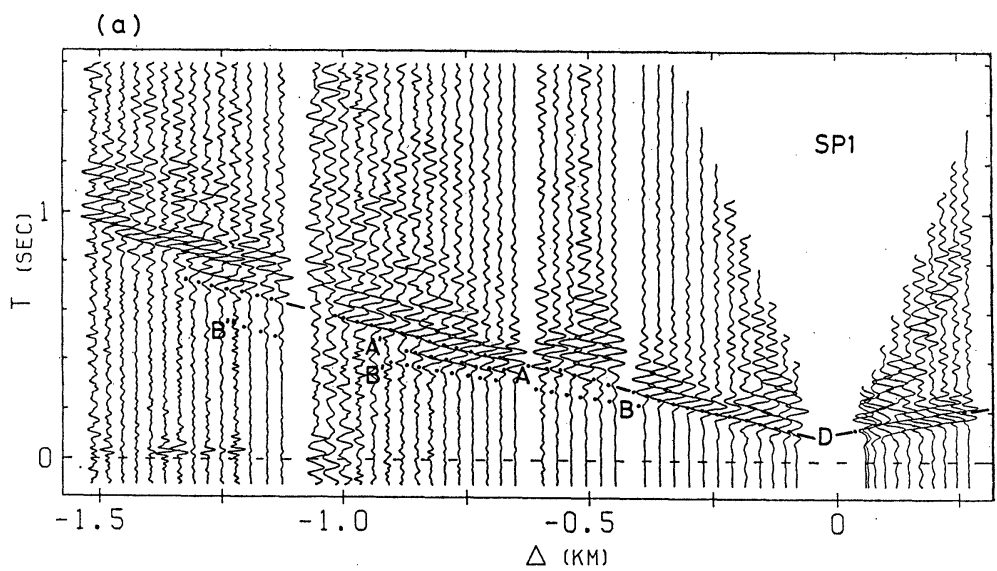

(b)
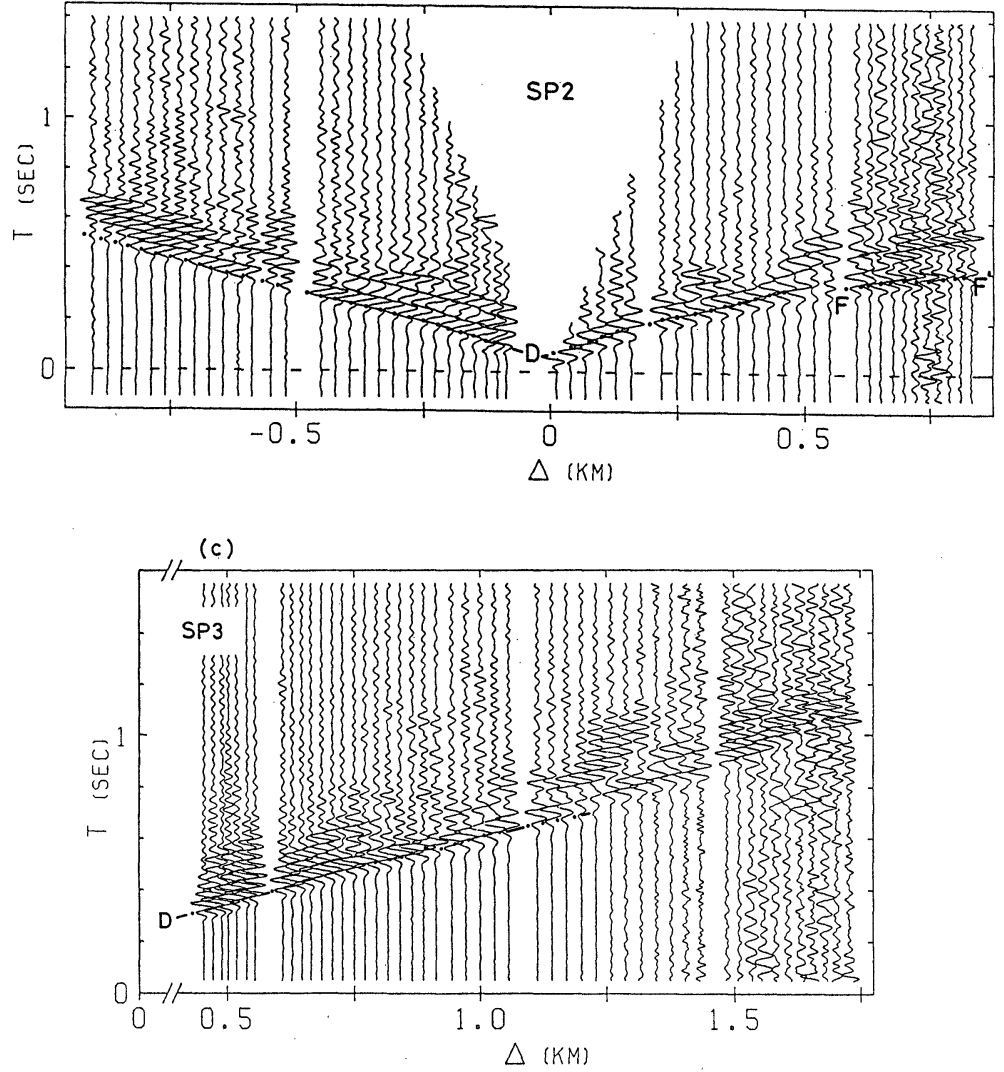


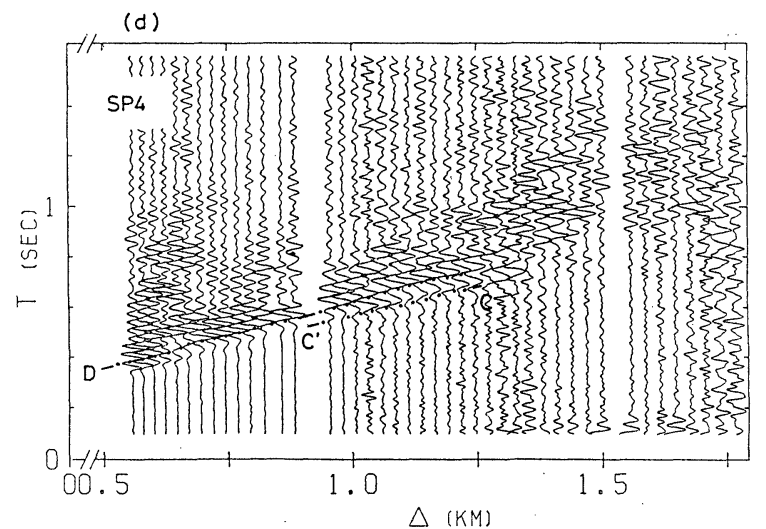

Fig. 3. Records for shots at SP1-SP4 stacked by 30 to 180 times to improve $\mathrm{S} / \mathrm{N}$ ratio and passed through a digital band-pass filter $(15-50 \mathrm{~Hz})$. Symbols A to $\mathrm{F}$ are the same as in Fig. 4.

これらの走時曲線を Fig. 4 に示 す.図中に示したよらに，○は初動の 走時を，記号 Dで示されたは初動 の後の山 (peak) の走時を示している. 初動は SP1・SP2 の近距離だけでし か精度良く決められないが，後続波 D は遠方まで明瞭である.またこの後続 波 $\mathrm{D}$ は，震源近傍では見か忖速度 1.6 $\mathrm{km} / \mathrm{s}$ 程度の直接波であるが，それ以 遠では約 $2.0 \mathrm{~km} / \mathrm{s}$ の速度を示してい る.これらをまとめて D で示してあ る.

Fig. 3 抌よび Fig. 4 によると，こ の地域では見かけ速度 $1.9 \sim 2.1 \mathrm{~km} / \mathrm{s}$ の層がたいへん厚いことが特徴的であ る. 特に田島川 (SP2) より西側では この層が発達している. SP3の記録で は $\Delta$ が $1 \mathrm{~km}$ 以上の距離まで下層の

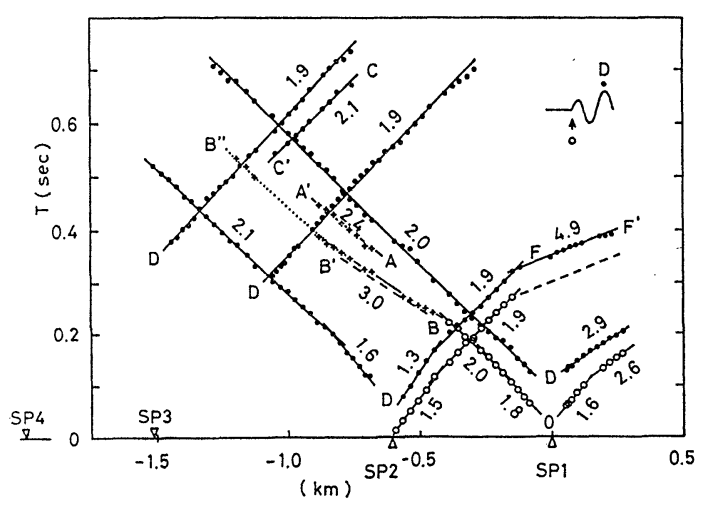

Fig. 4. Travel time curves for shots at SP1-SP4. Open circles indicate the first arrivals, and closed circles indicate later arrivals. Refracted phases $B-B^{\prime}$ and $F-F^{\prime}$ from the basement are notable in the eastern part of the spread, while they are absent in the western part. First motions of these refracted phases are indicated by broken lines because of their weakness.

屈折波が現われていない. SP4の記録では $1 \mathrm{~km}$ 以遠で D よりもやや見かけ速度の速い CC'が現われているが，この屈折波の見かけ速度は約 $2.1 \mathrm{~km} / \mathrm{s}$ である.ここでは見かけ速度 $1.9 \sim 2.1 \mathrm{~km} / \mathrm{s}$ を示す phase をいらいち区別せず，以後をとめて $2.0 \mathrm{~km} / \mathrm{s}$ として取り扱ら ことにする. SP1・SP2の記録においても，田島川 (SP2)の西側へはこの見かけ速度 $2.0 \mathrm{~km} /$ $\mathrm{s}$ の phase が特に顕著である.それに対し，田島川 (SP2) の東側では基盤からの屈折波と考 えられる $\mathrm{B}-\mathrm{B}^{\prime}, \mathrm{F}-\mathrm{F}^{\prime}$ が現われている. 以上のことから, 田島川 (SP2) の東側では基盤が浅 く西側ではそれが急に深くなつていることがわかる。 


\section{§3. 自然地震の観測と走時}

\section{1 自然地震の観測}

我々は $2 つ の$ 自然地震の解析を行ならことができた。

一つはェアガンを用いた今回の観測中に偶然観測されたものである. その時 15 個の地震計 は震源 SP2 のすぐ東側の測線に配置されており，測線長は約 $450 \mathrm{~m}$ であつた (Fig. 2). 記 録の $\mathrm{P}$ 波部分が Fig. 5 に示されている.これを「地震 $\mathrm{E} 1 」$ と呼ぶことにする.

もら一つの地震は，やや長周期微動の観測中 [古川・他 (1984)；春日 (1983)] にやはり偶 然観測されたものである. Fig. 2 の C-1 から C-8 に地震計が置かれ，8成分すべてを同一 のディジタルレコーダに記録中であつた．地震計は固有周期 2 秒の水平動であり，NS（南北） 成分のみが観測された．その S 波部分を Fig. 6 に示す。これを「地震 $\mathrm{E} 2 」 と$ 呼ぶことにす る. 水平動地震計であつたため， $\mathrm{P}$ 波の立ち上がりは確認できなかつた.

\section{2 自然地震の記録と走時}

2 つの地震はいずれも京都大学防災研究所北陸微小地震観測所の観測網により震源決定され た. 測線 L-L' の注汭中央にあたる SP2 の位置から見た 2 つ地震の震源を，震央距離 4 , 北から時計まわりの方位角 $\phi$, 震源の深さ $z$ で表わすと, 地震 $\mathrm{E} 1$ は $\Delta=14.1 \mathrm{~km}, \phi=18.8^{\circ}$, $z=3.0 \mathrm{~km}$ に, 地震 $\mathrm{E} 2$ は $\Delta=63.6 \mathrm{~km}, \phi=132.9^{\circ}, z=4.0 \mathrm{~km}$ に決定された.

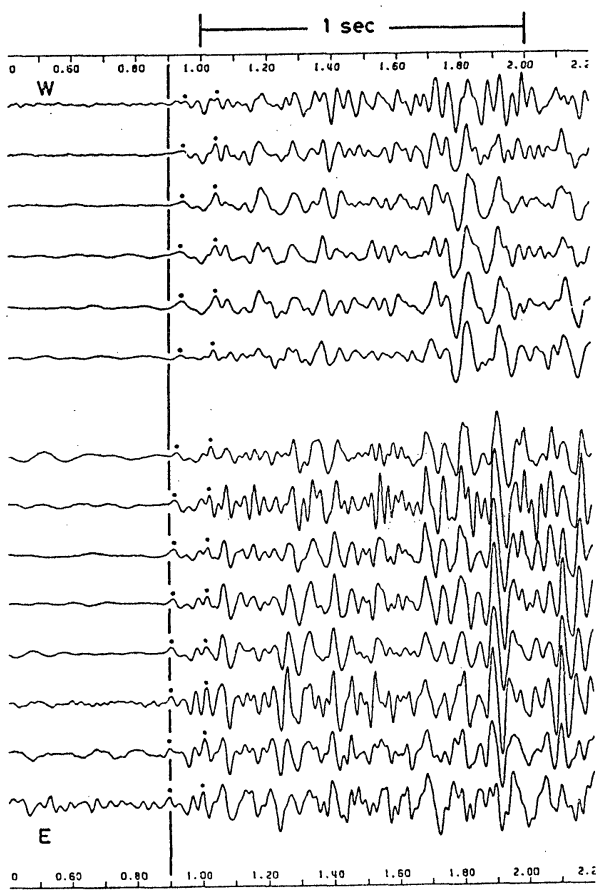

Fig. 5. Earthquake "E1" observed at the east of SP2. The P-wave groups observed by verticaltype tranceducers with natural frequency $8 \mathrm{~Hz}$ are shown. Closed circles indicate peaks of first and later arrivals.
地震 $\mathrm{E} 1 ・ \mathrm{E} 2$ の $\mathrm{P}$ 波执よび $\mathrm{S}$ 波 初動走時を震央距離に対してプロット したのが Fig. 7 である. 地震 E2 の 走時から明らかなように, $\mathrm{S}$ 波走時は 測線の西側部分で約 $2.8 \mathrm{~km} / \mathrm{s}$ の見か け速度を示すのに対し，測線の東側部 分では走時のとびを示している．地震 E1 にも同様の走時のとびが見える. な抗これら 2 つ地震の絶対時刻は観 測されていないため, トレース間の相 対時間 (delay time) だけが利用でき る.

\section{$\S 4$. 基盤構 造}

エアガン震源に対する 4 つの記録と 自然地震の 2 つ記録を利用して, 以 下地下構造を推定することにする.

まずェアガン震源の記録から検討し ていく. Fig. 4 から明らかなように, $\mathrm{SP} 1 \cdot \mathrm{SP} 2$ の近傍では $2.0 \mathrm{~km} / \mathrm{s}$ 層の 上に $1.5 \sim 1.8 \mathrm{~km} / \mathrm{s}$ の速度をもつ表 層が存在する、いまこの表層が一定の 速度 $1.6 \mathrm{~km} / \mathrm{s}$ であると仮定すれば， 
その厚さは約 $40 \mathrm{~m}$ となる. しかし $\mathrm{SP} 1$ は測線から $60 \mathrm{~m}$ 程離れているた めその time term に任意性があること や，この表層の厚さは測線の一部でし か決められない等の事情により, 以後 の議論では表層の存在を無視すること にする.これは $40 \mathrm{~m}$ の厚さの 1.6 $\mathrm{km} / \mathrm{s}$ 層を $2.0 \mathrm{~km} / \mathrm{s}$ 層とみなすこと に当るが，このことにより基盤の深さ は約 $10 \mathrm{~m}$ 深く求められることになる.

基盤からの屈折波と考光られる $\mathrm{B}-$ $\mathrm{B}^{\prime}, \mathrm{F}-\mathrm{F}^{\prime}$ の見か村速度はそれぞれ 3.0 $\mathrm{km} / \mathrm{s}, 4.9 \mathrm{~km} / \mathrm{s}$ である。これは“3.0 $\mathrm{km} / \mathrm{s}$ 層” “ “ $4.9 \mathrm{~km} / \mathrm{s}$ 層” の 2 層 が存在するためと考えることもできる し，あるいは層の傾斜による見か忛速 度の違いと考えることも可能である. しかし SP1 以外の震源の場合, 基盤 の深い田島川 (SP2) の西側には “3 $\mathrm{km} / \mathrm{s}$ 層” に対応する中間層の存在を 示唆する事実がないため, ここでは同 一の基盤層の傾斜により $\mathrm{BB}^{\prime}$ と $\mathrm{FF}^{\prime}$ とで異なる見かけ速度が表われている と考えることにする。このよらに仮定 して得られる基盤の $\mathrm{P}$ 波速度は 3.7 $\mathrm{km} / \mathrm{s}$ となり，その基盤面は Fig. 8 に太い実線で示した部分に対応する.

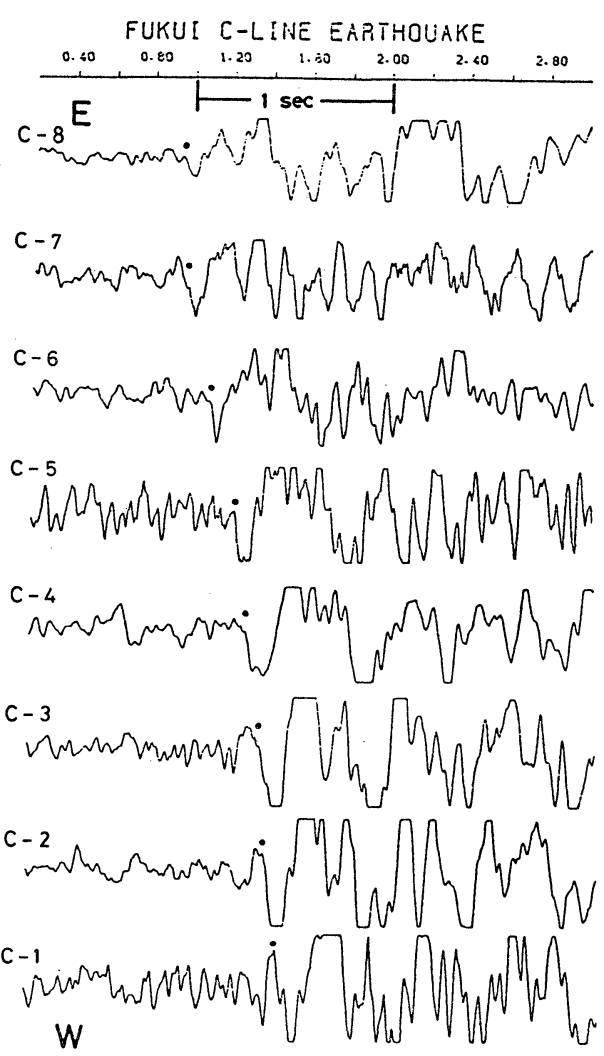

Fig. 6. Earthquake "E2" observed at $\mathrm{C} 1$ through $\mathrm{C} 8$. The S-wave groups observed by horizontaltype seismographs with natural period $2 \mathrm{sec}$ are shown. Closed circles indicate the first arrivals of the group.

四からわかるようにこの 2 つ屈折波は基盤の共通部分から生じた phase ではないから, 得 られた $3.7 \mathrm{~km} / \mathrm{s}$ といら速度は相当の誤差を含んでいる可能性がある. 当地の基盤岩は, 付近 の山地を形成する岩石も，測線のやや東で着岩したボーリングデータにおける基盤岩 [北陸農 政局計画部 (1977)] もとも新第三紀の火山岩類であることから, ほぼ同種の岩石から成ると 推察される. 服部・杉本 (1975) はこの付近の火山岩類の速度を $3.35 \mathrm{~km} / \mathrm{s}$ 以上と分類して おり，本測線下の基盤岩が付近の山地を形成する火山岩と同じ速度を持つとすれば， $3.7 \mathrm{~km} / \mathrm{s}$ という基盤岩の速度は服部・杉本（1975）の結果と矛盾するものではない.

田島川 (SP2) の西側では基盤からの屈折波が得られていないため，エアガン震源の記録か ら基盤の深さを求めることはできない。しかし SP2 では西側へ約 $0.9 \mathrm{~km}, \mathrm{SP} 3 \cdot \mathrm{SP} 4$ では 東側へ約 $1.0 \mathrm{~km}$ の距離まで基盤からの屈折波が現われていないといら制約により，西側の 基盤は水平層と仮定した場合 $270 \mathrm{~m}$ より深いことになる.

次に地震波の走時を用いて基盤構造を推定する。このためには基盤面の上下での $\mathrm{S}$ 波速度 
を求めなければならない。基盤面までの速度は，別の機会に行なつた板たたき法による $\mathrm{S}$ 波 探査の結果を参考にした．この時，基盤までの中間層からの反射波が観測され，その走時から 表層の沖積層を除いた洪積層の速度はおよそ $500 \sim 600 \mathrm{~m} / \mathrm{s}$ であることがわかつた（未公表資 料).そこで，ここでは基盤までの $\mathrm{S}$ 波速度を $600 \mathrm{~m} / \mathrm{s}$ と仮定することにする．P 波速度 $2.0 \mathrm{~km} / \mathrm{s}$ の洪積層の $\mathrm{S}$ 波速度を $600 \mathrm{~m} / \mathrm{s}$ とすることは不自然でない[例えば，物理探鉱技 術協会 (1977) ; 今井 (1976)]. 基盤の S 波速度も同じ文献を参考にして $2.0 \mathrm{~km} / \mathrm{s}$ と仮定し た. また地震 $\mathrm{E} 1 ・ \mathrm{E} 2$ のどちらも震央距離に対する測線長の比が $3 \%$ 以下と小さいため，地 震は十分遠く，基盤へは平面波が入射したと仮定した。

地震 $\mathrm{E} 2$ の $\mathrm{S}$ 波は Fig. 7 に示すように明らかな走時のとびを示す。ここではこれを基盤 の深さの違いによると考兄て，基盤までの深さを求めることにする．方法は，見かけ速度一定 の平面波が基盤に入射したと考光，走時差を表層の厚さの差に換算するものである。この方法 では直接基盤の深さは求められないから，これを測線の東側部分で屈折波から求めた基盤に一 致させるようにするまた測線の西側部分では；前述したように基盤が $270 \mathrm{~m}$ より深いとい う要請がある.これらを満すように求めた構造が Fig. 8 にロで示してある. その際，基盤に 入射する $\mathrm{S}$ 波の見か忖速度として $3.9 \mathrm{~km} / \mathrm{s}$ の值を用いたが，それは以下の理由によるもの である. 地震 $\mathrm{E} 2$ の震央距離 $(63.6 \mathrm{~km})$ と深さ $(4.0 \mathrm{~km})$ から考えて, 観測された $\mathrm{S}$ 波は上 部地殼を伝わつた直接波と考えられるため，基盤に入射する平面波の見かけ速度として 3.9

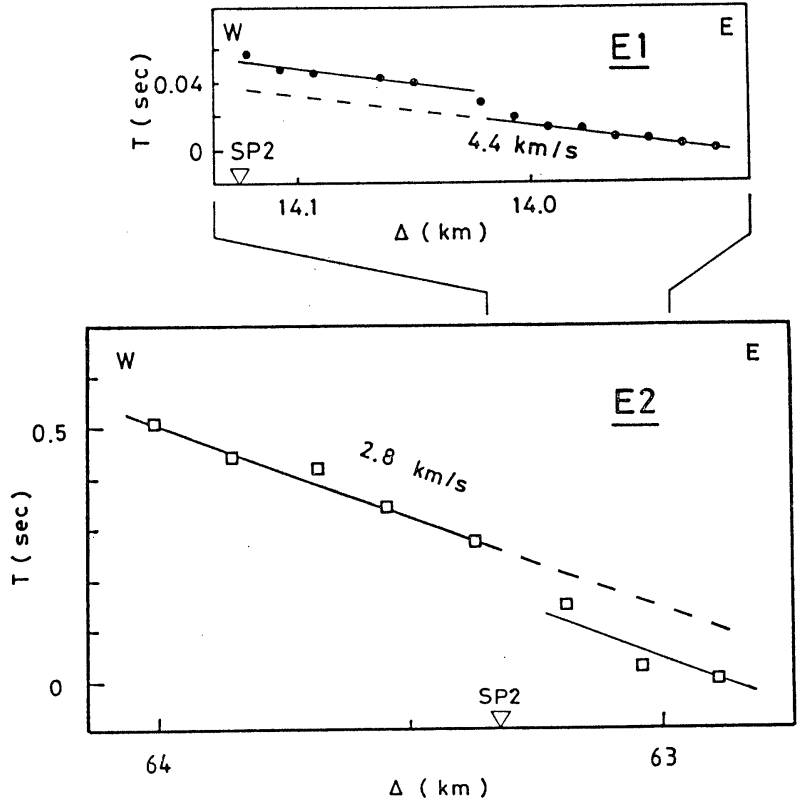

Fig. 7. Delay times read from Fig. 5 for P-phases and from Fig. 6 for S-phases. The travel time at the most eastern observation point in each event is reduced to zero because only time differences among observation points were available. Traveltime gap at $63.3 \mathrm{~km}$ from the epicenter is noticeable in the bottom figure. 


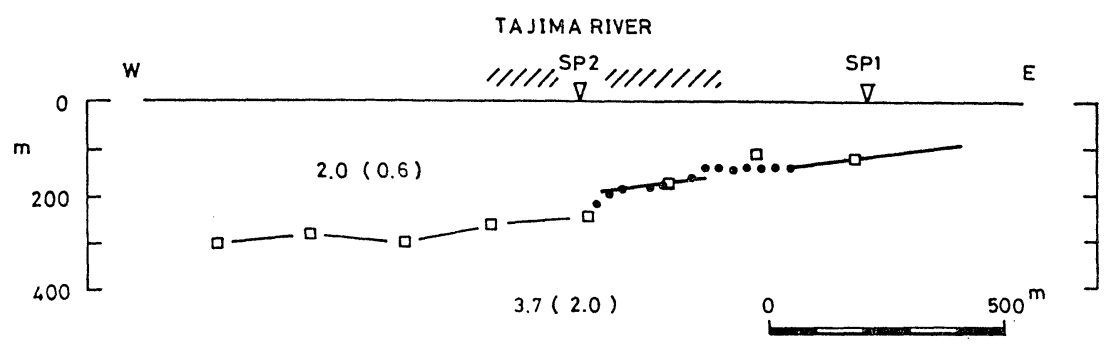

Fig. 8. Estimated basement profile. An abrupt change in basement depth can be seen around SP2. Many fissures and cracks were found in the hatched area around SP2 soon after the Fukui Earthquake in 1948.

$\mathrm{km} / \mathrm{s}$ よりあまり大きな值は考圠くいこと，一方，この入射波の見かけ速度を $3.9 \mathrm{~km} / \mathrm{s}$ よ り小さくすると西側の基盤が浅くなりすぎて，とれが $270 \mathrm{~m}$ より深いといら前述の条件と矛 盾してくることである.したがつて，この $3.9 \mathrm{~km} / \mathrm{s}$ といら入射波の見かけ速度をとれほど大 きく変えることはできない，な和この入射平面波の見かけ速度を $\pm 0.4 \mathrm{~km} / \mathrm{s}$ だけ変えると， 東端 (C8) を固定した場合, 最も離れた西端 $(\mathrm{C} 1)$ でも基盤の深さは $+23 \sim-29 \mathrm{~m}$ 変化する だけであり，構造は入射波の見かけ速度にそれ汪ど敏感には影響されない．また測線の西側部 分で $\mathrm{S}$ 波の見かけ速度が $2.8 \mathrm{~km} / \mathrm{s}$ とやや遅いことは，基盤が西に傾斜していることを示す と考学らる。

地震 $\mathrm{E} 1$ についてもほぼ同様の考察を行ない, これから得られた構造が Fig. 8 にで示さ れている.

以上，エアガン震源の記録と自然地震の記録の走時を用いて，福井地震断層を横断する基盤 構造モデルを作成した．Fig. 8 を見ると，SP2（田島川）付近で基盤が数十 $\mathrm{m}$ くい違つてお り，さらに SP2 より約 $250 \mathrm{~m}$ 東にも小さなくい違いがあるように見える．田島川をはさんで ハッチで示した部分は 1948 年の地震の際多数の地割れを生じた場所であり, 我々の求めた段 差はまさにその直下に位置している．すなわちこの段差は，1948 年の福井地震およびそれに 先行する度重なる地震によつて上下変位が蓄積された地震断層であると推理することができる. 他の根拠との関連は次節に詳述する.

Fig. 3a, Fig. 4 には $\mathrm{B}^{\prime}-\mathrm{B}^{\prime \prime}$ phase が見られるが，これを SP2 の下の基盤の edge から 来た diffraction phase と考えて描いた走時が Fig. 4 に点線で示されている.このように $\mathrm{B}^{\prime \prime}$ 付近の phase を断層からの diffraction phase と考えても走時的に不自然ではなく, や はり上記の断層構造の妥当性を支持するものと考えられる.

\section{§5. 他資料との比較と福井地震断層の活動度}

前節では福井地震断層を横断する基盤構造を推定し, 地震に由来すると考えられる断層につ いて言及したが，ここでは他資料との比較を行なうことによりさらに断層について考察する.

Fig. 9(a) は福井地震前後に行なわれた水準測量から求められた地表面の垂直変位を示して いる [TSUYA (1950)]. この困が得られた測線は本観測の測線より数百 $\mathrm{m}$ 南に位置し, 最大 上下変位は約 $50 \mathrm{~cm}$ とされている. な扔測量から得られた福井地震の際の最大上下変位は約 $70 \mathrm{~cm}$ であり, 場所はこの地点よりほぼ $3 \mathrm{~km}$ 南南東であつた. Fig. 9(b) は竹内・天池 
（1984）による地表面の標高を示している，大きな黒丸は水田の標高，小さな黒丸は小さな農 道の標高であり, 図中の $\mathrm{h}$ は福井地震の最大上下变位量である. 現在の地形にも福井地震によ る上下変位が残されているが, 地形に残された “变位量” は 1948 年の地震の上下変位量を越 しているように見える. 竹内・天池 (1984) は当地よりさらに南方でこの “変位量”が数 $\mathrm{m} に$ も及び，1 回の地震発生では説明できないことを指摘している. Fig. 9(c) はボーリング資料 [北陸農政局計画部 (1977]) による沖積層と洪積層の境界を示す. 断層をはさんでやはり $10 \mathrm{~m}$ 程度のくい違いが存在するようである.Fig. 9(d) は前節で推定された基盤構造であり，東部 の山地を含む地形も示されている．B の境界はここでボーリングが着岩した [北陸農政局計画 部 (1977) ] ことを示している. 田島川 (SP2) 付近のハッチ部分には福井地震の際多数の地割 れが生じたことを示している.

(a) Changes in Land-level

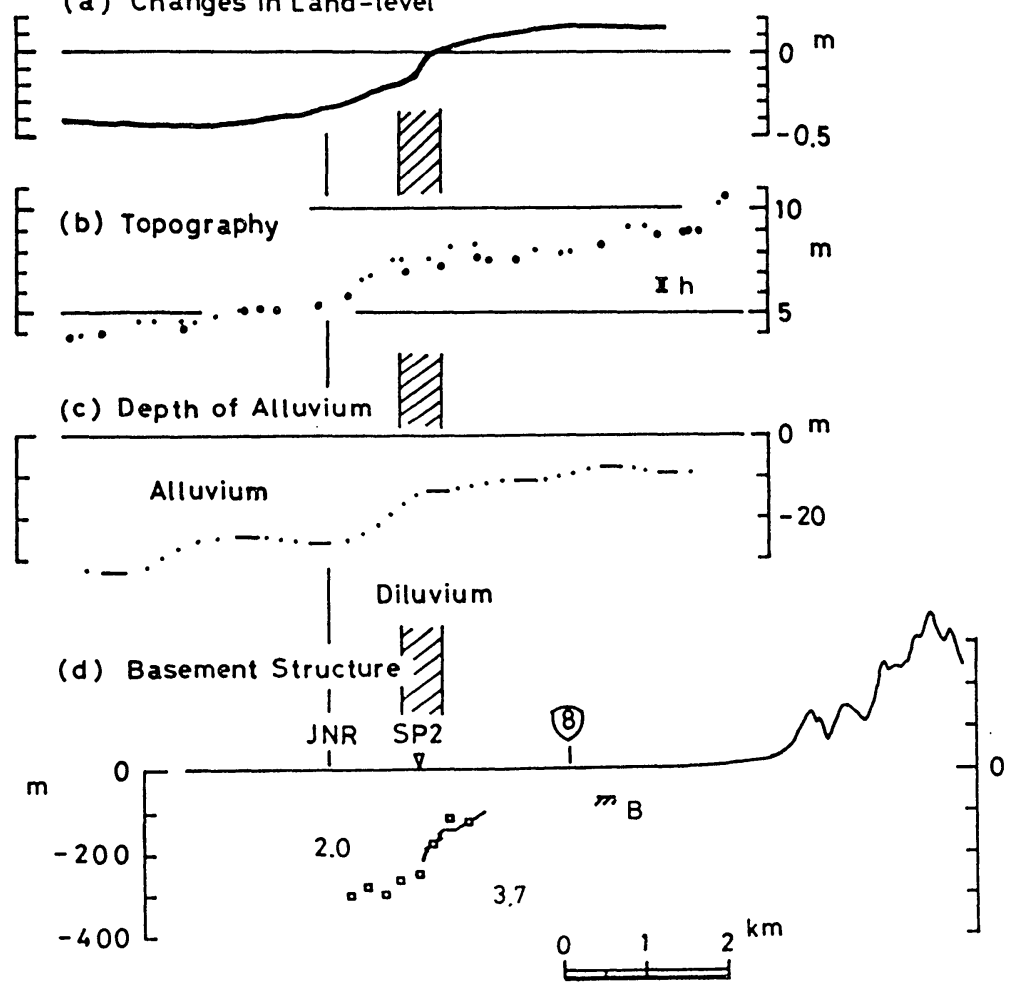

Fig. 9. The hatched area denotes the zone of fissures and cracks which were found soon after the Fukui Earthquake in 1948. (a) Changes in land level associated with the Fukui Earthquake in 1948 [after TSUYA (1950)]. (b) Circles indicate heights above the sea level. Large and small circles indicate data sampled on the rice fields and on the small roades crossing them, respectively [after TAKEUCHI and AMAIKE (1984)]. (c) The bottom of the alluvium in the western side is deeper by about ten meters than that in the eastern side of the fault [after HoKURIKU NOUSEI-KYoKU KEIKAKU-BU (1977)]. (d) Basement Structure estimated in this study. All figures (a) to (d) suggest the presence of the buried fault around SP2 (Tajima river). 
以上を総合すると，地震時に 発生した地割れ帯や (a)〜 (d) に示す諸量がいずれも田島川 (SP2) 付近で上下にくい違つており，乙かも下部葟どそのくい違い量が大きいことになる．乙 たがつて，田島川 (SP2)の下にはくり返し地震を発生させた活断層が存在すると結論すること ができる.

Fig. 9(d) に示すように，今回得られた基盤は抢そらく基盤 B に連なり，さらに東部山地を 形成する火山岩に連なるものと推定される。このように巨視的な目で見ると基盤は今回の測線 全体で西へ急に深くなつていることがわかる，したがつて，前節で指摘したよらに田島川 (SP2) の下付近に $1 \sim 2$ 本の断層面を考劣ることもできるが，この測線全体を断層帯と考学る ことも可能である.この点についての詳細な議論は現在のデータからだけではできない、した がつて解釈に幅はあるものの, 基盤の段差は小さく見積つても数十 $\mathrm{m}$, 大きく見積れば 150 $200 \mathrm{~m}$ 程度と考えられる.

一方, 地震に伴なら基盤の段差を論じる場合以下の点を考慮する必要がある. Fig. 9(d) に 示された基盤深さの急変は東部山地の地形変化と比べて特に著しいといら程のものではなく, 基盤の段差がすべて地震により形成されたものかどうか。また福井地震断層は主要には横ずれ 断層であるから, 基盤の水平ずれにより見かけ上の段差を生じた可能性はないかといら点であ る.これらの点については, 現在のところ詳細な議論はできない.

ここでは基盤のくい違いをくし返し発生した地震の結果と考光，そのくり返し周期について 簡単な考察をしてみたい, 岡田・安藤 (1979) によると, 日本の主要な活断層は「第四紀初頭 頃から動き始め，それ以後，変位速度と運動方向がほぼ一様である [MATSUDA (1976)]」が， 「最近では第四紀後期 (70 30 万年前) から断層運動が激化し, 現在に向つて変位速度を増し ている例が中央構造線や近畿内帯の活断層で報告されている」という.さらに安藤 (1979) は 「(日本)列島のどこに位置するかで少々開始の時期が異なる」が，「いまから50万年前より現 在に至るまでは，日本列島のどこをとつてみても一様な変動が続いている」としている．この ように活断層は, 通常第四紀または第四紀後期になつてから活発に動き始めたと考えられてい るため, 福井地震断層も仮に 100 万年前から動き始めたと考えて, 基盤の段差から垂直方向の 平均変位速度を求めると 1000 年につき $5 \sim 20 \mathrm{~cm}$ となる. また沖積層と洪積層の境界が約 $10 \mathrm{~m}$ ずれている (Fig. 9) ことから得られる平均変位速度は 1000 年につき $50 \mathrm{~cm}$ となり, 基盤の段差から得られた值よりいくぶん大き目である.

さてこの断層が 1948 年の地震とほぼ同じ量（約 $1 \mathrm{~m}$ ) だけ地震の度に上下変位を蓄積して きたとすれば，既に 50２00 回地震が発生し，そのくり返し周期は 2,000～20,000 年となる. また 1948 年の地震時の動きから考えて水平変位速度を垂直変位速度の 2 倍程度と見積れば, 前者は 1,000 年につき $0.1 \sim 1 \mathrm{~m}$ となり, 松田 (1975) の分類法に従うと福井地震断層は $\mathrm{B}$ 級の活断層ということになる. 平均変位速度・地震のくり返し周期等についてはここでは概算 にとどまり，さらに精度の良い研究は今後に期待したい。

\section{謝辞}

新日本技術コンサルタント株式会社, 阪神コンサルタンツ株式会社にはエアガンの借用・運 搬等でお世話になつた，坂井・丸岡・春江の関係各町および坂井町田島・脇田満氏, 坂井町若 宮・稲沢組には観測のための便宜をはかつていただいた。観測および解析にあたつては小林芳 
正助教授・入倉孝次郎助教授の援助・助言をいただいた．観測では京大理学部・川部喜朗氏， 京大防災研・西上欽也氏の補助を得た。 また，小林芳正助教授・安藤雅孝博士には原稿を読ん でいただいた，記して謝意を表します。

なおデータ処理には京都大学大型計算機センターの FACOM M380・M382 を用いた。本 研究の費用の一部は文部省科学研究費 [課題番号 57740203] によつた.

\section{文献}

Amaike, F., S. Kasuga, K. Kisimoto, T. Iwata, K. Irikura and Y. Kobayashi, 1982, Estimation of Base Rock Structure using Reflected Waves, Proc. 6th. Japan Earthq. Engin. Spmp., 57-64.

天池文男・春日 茂・岸本清行・小林芳正・岩田知孝・入倉孝次郎， 1984 , 反射波を用いた京都盆地 東南部の基盤構造の推定, 地震 $2,37,185-196$.

安藤雅孝, 1979, 日本列島の最近 50 万年の応力場, 月刊地球, 1, 541-546.

物理探鉱技術協会, 1977, 土木弾性波探査法, 374-438.

服部保正・杉本卓司, 1975, 岩石のP 波伝播速度に関する統計的研究 (II), 物理探鉱, 28, 43-56.

北陸農政局計画部, 1977, 福井県の水理地質と地下水, 北陸農政局計画部.

古川信雄・竹内文朗・春日 茂・平野憲雄・天池文男, 1983, 福井地震断層周辺でのやや長周期微動 観測, 京都大学防災研究所年報, 26B, 123-134.

古川信雄・春日 茂・竹内文朗・天池文男, 1984, やや長周期微動の群列観測による福井地震断層探 查, 地震 $2,37,207-215$.

今井常雄, 1976, S 波測定値と他の物理量との関連, 地震波の生成・伝播に関する実験, 地震探鉱実 験グループ, 77-83.

春日 茂, 1983 , 表層に覆われた断層近傍に批りる微動の振幅变化, 昭和 58 年度地震学会春季大会講 演予稿集, 190 .

活断層研究会, 1980, 日本の活断層一分布図と資料.

河野芳輝 - 角南基亮・藤井美智子, 1981, 福井平野に批る重力異常と福井地震災害との関係, 地震 $2,34,377-383$.

松田時彦，1975, 活断層から発生する地震の規模と周期について，地震 2, 28, 269-283.

Matsuda, T., 1976, Empirical Rules on Sense and Rate of Recent Crustal Movements, J. Geod. Soc. Japan, 22, 252-263.

岡田篤正・安藤雅孝, 1979, 日本の活断層と地震, 科学, 49, 158-169.

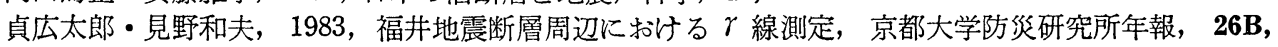
$117-122$.

斉藤正徳，1978, 漸化式ディジタル・フィルターの自動設計，物理探鉱，31，240-263.

竹内文朗 - 平野憲雄・古川信雄, 1983a, 福井地震断層探査 その 1 全磁力, 昭和 58 年度地震学会 春季大会講演予稿集, 219 .

竹内 文朗 - 古川 信雄・春日 茂・平野憲雄・西上欽也・見野和夫 - 天池文男 - 川部喜朗 - 河野芳輝 貞広太郎, 1983b, 福井地震断層の位置と規模を定めるための探査, 地震予知連絡会報, 30, 368一 375.

Takeuchi, F., N. Hirano, M. Satomura, and Y. Kono, 1983, Observation of Gravity to Reveal a Buried Fault Associated with the Fukui Earthquake, Bull. Disas. Prev. Res. Inst., Kyoto Univ., 33, 147-162.

竹内文朗・天池文男, 1984, 地形図にみられる, 福井地震のくり返しによる地表面の上下变位につい $\tau$, 地震 2 (準備中).

TsuYA, H. (edited), 1950, The Fukui Earthquake of June 28, 1948, Report of the Special Committee for the Study of the Fukui Earthquake.

宇佐美龍夫, 1975, 資料日本被害地震総覧, 東京大学出版会.

吉川宗治, 1949, 福井地震の震害と地盤, 防災研究所報告, 2 号, 12-16. 